\title{
KARAKTERISTIK ROTI TAWAR KAYA SERAT YANG DISUBSTITUSI MENGGUNAKAN TEPUNG AMPAS KELAPA
}

The Characteristics of Fiber-Rich White Bread Substituted by Coconut Dregs Flour

\author{
Deni Antra Pusuma ${ }^{1) *}$, Yhulia Praptiningsih ${ }^{1)} *$, Miftahul Choiron ${ }^{1)}$ \\ ${ }^{1)}$ Jurusan Teknologi Hasil Pertanian, Fakultas Teknologi Pertanian, Universitas Jember \\ Jl. Kalimantan 37, Kampus Tegal Boto Jember 68121 \\ *E-mail: deny.antra09@gmail.com, yhuliaprapti@gmail.com
}

\begin{abstract}
Indonesia's wheat imports reached 7.49 until 8.10 million tons or ranked second world after Egypt based on data from the Department of Agriculture of the United States (USDA) in the year of 2014/2015/2016. By 2020, projected wheat imports will be increase threefold from the previous year. The consumption of wheat flour in bread production could be decreased by coconut dregs flour as substitute of wheat flour. The research was formulated the fiber-rich white bread using wheat flour and coconut dregs flour with ratio 100\%:0\%, 95\%:5\%, 90\%:10\%, 85\%:15\%, and 80\%:20\%. The aim of this research was to know the physical, chemical, sensory properties and crude fiber content of white bread with good quality and high preference. The result showed that the substitution of coconut dregs flour was 10\%. The bread had an inner and outer texture of $54.80 \pm 0.8 \mathrm{~g} / 10 \mathrm{~mm}$ and $195.03 \pm 0.86 \mathrm{~g} / 10 \mathrm{ml}$; lightness of 23.64 ; loaf volume bread of $147.27 \pm 1.4 \%$; uniform slice appearance; moisture content of $39.07 \pm 0.12 \%$; ash content of $1.47 \pm 0.15 \%$; protein content of $9.59 \pm 0.3 \%$; fat content of $6.13 \pm 0.49 \%$; carbohydrate content about $44.11 \pm 0.72 \%$; crude fiber content about 5.69\%; score of preference color, aroma, taste, texture and overall respectively about 5.37; 5.30; 5.27; 5.50; 5.43 (rather like to like).
\end{abstract}

Keywords: coconut dregs flour, crude fiber, white bread

\section{PENDAHULUAN}

Roti merupakan salah satu pangan olahan yang terbentuk dari fermentasi terigu dengan menggunakan ragi (Saccharomyces cerevisiae) atau bahan pengembang lainnya kemudian dipanggang (Mudjajanto dan Yulianti, 2004). Roti khususnya roti tawar merupakan salah satu pangan olahan dari terigu yang banyak dikonsumsi oleh masyarakat luas. Roti tawar merupakan salah satu jenis roti sponge yang sebagian besar tersusun dari gelembung-gelembung gas. Harga yang relatif murah, menyebabkan roti tawar mudah dijangkau oleh seluruh lapisan mayarakat baik dari lapisan bawah, menengah hingga atas. Hal ini dapat dibuktikan dengan semakin banyaknya industri roti baik dalam skala rumah tangga maupun industri menengah.

Bahan baku utama pada pembuatan roti tawar adalah tepung terigu, sedangkan bahan dasar pembuatan tepung terigu adalah gandum. Sampai saat ini, Indonesia masih mengimpor gandum dan impor terigu terus meningkat. Departemen Pertanian Amerika Serikat (USDA) pada 2014/2015 menyatakan bahwa impor gandum Indonesia mencapai 7,49 juta ton atau menduduki peringkat kedua dunia setelah Mesir 11,06 juta ton. Tahun 2015/2016 mencapai 8,10 juta ton atau menduduki peringkat dua setelah Mesir 11,50 juta ton. Tahun 2020, diproyeksikan impor gandum akan meningkat tiga kali lipat dari tahun sebelumnya (Listiyarini, 2016). Oleh karena itu, untuk menurunkan kenaikan konsumsi terigu maka perlu ada upaya alternatif untuk mengurangi penggunaannya dalam pembuatan roti. Solusi untuk mengurangi penggunaan terigu pada pembuatan roti tawar adalah dengan mengganti sebagian terigu (substitusi) dengan tepung lain yaitu 
tepung ampas kelapa. Hal ini merupakan salah satu upaya dalam memanfaatkan limbah kelapa yaitu berupa ampas kelapa.

Ampas kelapa merupakan hasil samping dari proses pengambilan santan kelapa. Selama ini ampas kelapa hanya dimanfaatkan sebagai pakan ternak dan sebagian dijadikan tempe bonkrek untuk makanan. Putri (2010) menyatakan bahwa ampas kelapa mengandung serat kasar yang cukup tinggi sebesar $15,07 \%$. Ampas kelapa mengandung selulosa cukup tinggi yang dapat berperan dalam proses fisiologis tubuh. Selulosa merupakan serat makanan yang tidak dapat dicerna oleh enzim-enzim pencernaan, namun peranannya dalam sistem pencernaan sangat penting karena dapat memperpendek waktu transit sisa-sisa makanan, sehingga mengurangi resiko kanker usus (Muchtadi, 1989). Tepung ampas kelapa adalah tepung yang diperoleh dengan cara menghaluskan ampas kelapa yang telah dikeringkan. Tepung ampas kelapa dapat dibuat dari kelapa parut kering yang dikeluarkan sebagian kandungan lemaknya melalui proses ekstraksi secara mekanik yaitu dengan pengepresan (Rony, 1993).

Pada proses pembuatan roti tawar yang berperan penting dalam pembentukan tekstur dan pengembangan adonan adalah senyawa gluten yang terkandung dalam gandum. Gluten menentukan elastisitas dan plastisitas adonan yang diakibatkan terbentuknya kerangka seperti jaring-jaring yang berperan sebagai perangkap gas hasil peragian sehingga adonan dapat mengembang (Wijayanti, 2007). Peranan substitusi terigu menggunakan tepung ampas kelapa dalam pembuatan roti tawar adalah untuk meningkatkan kandungan serat roti tawar sehingga dihasilkan roti tawar yang mempunyai nilai fungsional. Serat merupakan salah satu komponen pangan fungsional, yang berperanan untuk membantu proses pencernaan. Tepung ampas kelapa tidak mengandung gluten sehingga penggunaan tepung ampas kelapa sebagai substitusi terigu dalam pembuatan roti tawar perlu dibatasi.

Penelitian tentang pembuatan roti yang menggunakan berbagai macam tepung substitusi sebelumnya sudah dilakukan diantaranya adalah pembuatan roti yang dengan substitusi tepung singkong dan tepung kedelai (Arlene, 2009). Sudarmo (2015) menyatakan bahwa penambahan tepung kulit ari kedelai pada pembuatan roti dengan karakteristik dan sifat organoleptik yang masih baik dan disukai maksimal sebanyak 30\%. Namun, penggunaan tepung ampas kelapa untuk substitusi pada pembuatan roti tawar belum dilakukan.

\section{METODE PENELITIAN}

\section{Alat dan Bahan}

Peralatan yang digunakan dalam proses pengolahan ini antara lain loyang, copper, oven, neraca analitik Ohaous Ap310-O, ayakan 40 mesh, baskom, plastik, tissue, rolling pin. Alat yang digunakan dalam proses analisis adalah rheotex, colour reader CR-100, beaker glass, eksikator, destilator, kurs porselen, soxhlet, gelas ukur, tabung kjedhal, botol timbang, erlenmeyer, kertas saring dan kuisioner.

Bahan-bahan yang digunakan dalam penelitian ini antara lain kelapa yang dibeli di pasar Tegal Besar Kabupaten Jember, tepung terigu protein tinggi cap cakra kembar premium, air putih (merk Aqua), garam dapur (merk Tiga Daun), gula pasir (merk Gulaku), ragi instant, mentega (merk Blue Band), dan susu bubuk (merk Dancow). Bahan yang digunakan untuk analisis yaitu $\mathrm{H}_{2} \mathrm{SO} 4$, aquades, $\mathrm{NaOH}$, $\mathrm{K}_{2} \mathrm{SO} 410 \%$, selenium, asam borat $4 \%$, metil merah dan biru, $\mathrm{HCl}$, petroleum benzen, dan aseton.

\section{Tahapan Penelitian}

\section{Pembuatan tepung ampas kelapa}

Kelapa dikupas dengan cara memisahkan antara daging buah dengan 
kulit sabut dan tempurungnya, lalu airnya dibuang. Kelapa yang sudah dikupas ditempatkan di dalam satu wadah dan siap untuk diparut. Selanjutnya dilakukan ekstraksi dengan menambahkan air bersih ke dalam parutan kelapa dengan perbandingan 2 liter air untuk $1 \mathrm{~kg}$ kelapa lalu diperas sebanyak dua kali menggunakan tangan untuk mengambil santannya.

Hasil perasan kelapa ditampung di dalam toples plastik. Proses pemerasan kelapa ini dilakukan dua kali. Jadi, ampas padatan hasil perasan pertama dicampur lagi dengan air bersih, lalu diperas dan hasil perasan disaring dan ditampung di dalam toples plastik. Setelah itu dilakukan pengepresan kembali dengan menggunakan pompa hidrolik dan diulangi sebanyak dua kali pengulangan. Setelah itu dikeringkan pada pengering kabinet pada suhu $60^{\circ} \mathrm{C}$ selama 24 jam. Ampas kelapa setelah melalui proses pengeringan kemudian digiling menggunakan copper dan diayak menggunakan ayakan 40 mesh untuk mendapatkan tepung ampas kelapa.

\section{Pembuatan roti tawar substitusi tepung ampas kelapa}

Bahan-bahan yang diperlukan dipersiapkan terlebih dahulu seperti tepung ampas kelapa, terigu, mentega, gula, garam, air, susu, telur dan ragi instant. Bahan berupa terigu dan tepung ampas kelapa dicampur ke dalam wadah. Bahan lainnya seperti ragi, susu bubuk, dan gula dimasukkan ke dalam wadah yang telah terisi tepung campuran dan dicampur hingga merata. Setelah tercampur dengan merata, garam dan mentega putih dimasukkan ke dalam wadah tersebut dan diuleni hingga menjadi adonan yang kalis.

Adonan yang telah kalis didiamkan untuk proses fermentasi selama 30 menit. Fermentasi dilakukan dengan menutup adonan menggunakan plastik hingga rapat agar tidak ada udara yang masuk. Proses fermentasi dilakukan bertujuan untuk menghasilkan gas $\mathrm{CO}_{2}$ dan alkohol agar adonan dapat mengembang secara sempurna. Setelah 30 menit, adonan yang sudah mengembang digilas dengan rolling pin dan dicetak di dalam loyang khusus roti tawar. Penggilasan bertujuan agar sebagian udara yang terdapat di dalam adonan dapat keluar.

Selanjutnya adonan didiamkan kembali (proofing) pada suhu kamar selama 90 menit di dalam loyang kemudian ditutup menggunakan plastik. Proses proofing dilakukan untuk mengembangkan adonan hingga mencapai bentuk dan mutu yang baik. Selanjutnya adonan dipanggang pada suhu $160^{\circ} \mathrm{C}$ selama 40 menit menggunakan pemanggang oven. Roti tawar yang telah mengalami proses pengovenan dikeluarkan dari loyang kemudian didinginkan.

\section{Rancangan Percobaan}

Penelitian ini merupakan penelitian eksperimental dengan satu faktor yaitu rasio terigu dan tepung ampas kelapa dengan lima perlakuan dan tiga kali ulangan. Perbandingan rasio terigu dan tepung ampas kelapa yaitu (100\%:0\%, 95\%:5\%, 90\%:10\%, 85\%:15\%, 80\%:20\%). Data yang diperoleh dianalisis secara deskriptif. Rerata nilai yang didapatkan dari hasil analisis ditampilkan dalam bentuk tabel dan grafik disertai dengan error bars sebagai standar deviasinya.

\section{Metode Analisis \\ Sifat fisik}

Analisis fisik pada roti tawar substitusi tepung ampas kelapa meliputi analisis tekstur menggunakan rheotex (Sudarmadji et al., 2010), pengukuran warna (lightness) menggunakan colour reader Minolta CR-10, pengukuran daya kembang menggunakan metode seed Diplancement Test, pengukuran staling dan kenampakan irisan. 


\section{Daya kembang}

Daya kembang merupakan perbandingan kenaikan volume roti tawar dengan volume adonan awal. Pengukuran volume cetakan dilakukan dengan memasukkan millet dalam cetakan adonan sampai permukaan rata, setelah itu millet diukur volumenya dengan gelas ukur dan dicatat sebagai V1. Selanjutnya dilakukan pengukuran volume adonan sebelum dioven dengan menggunakan cetakan yang sudah diketahui volumenya (V1), kemudian adonan dimasukkan cetakan dan mengisinya dengan millet sampai batas yang penuh dan dicatat volumenya sebagai V2. Selanjutnya dilakukan pengukuran volume roti yang telah dioven dengan memasukkan millet pada wadah yang berisi roti tawar sampai tanda batas penuh, kemudian millet diukur pada gelas ukur sebagai V3 (Bakri, 1990).

\section{Staling}

Setiap roti tawar dengan masingmasing perlakuan dipotong menjadi empat bagian dan dikemas dalam plastik, kemudian dimasukkan dalam kotak ultraviolet selama 30 menit setelah itu kotak ultraviolet dimatikan dan sampel roti tawar tetap didalamnya. Roti tawar yang telah disimpan tersebut diamati tekstur setiap hari mulai dari hari ke-1 sampai hari ke-3. Pengukuran tekstur (menggunakan rheotex).

\section{Kenampakan irisan}

Kenampakan irisan dianalisis menggunakan metode pemotretan. Roti tawar yang telah diiris dengan ketebalan $1,5 \mathrm{~cm}$ kemudian diletakkan diatas alas putih dan dilakukan pemotretan.

\section{Uji organoleptik}

Uji organoleptik dilakukan untuk mengetahui tingkat kesukaan atau kelayakan suatu produk agar dapat diterima oleh panelis atau konsumen Menggunakan uji hedonik. Metode pengujian yang dilakuakan adalah metode hedonik (uji kesukaan) meliputi warna, aroma, tekstur dan rasa dari produk yang dihasilkan. Dalam metode hedonik ini, panelis diminta memberikan penilaian berdasarkan tingkat kesukaan. Skor yang digunakan adalah 7 (sangat suka), 6 (suka), 5 (agak suka), 4 (netral), 3 (agak tidak suka), 2 (tidak suka), 1 (sangat tidak suka).

\section{Uji efektivitas}

Uji efektivitas dilakukan berdasarkan metode indeks efektivitas untuk mengetahui perlakuan terbaik (de Garmo et al., 1984). Prosedur uji efektivitas yaitu membuat bobot nilai pada masing-masing variabel dengan angka antara 0-1. Bobot nilai diberikan tergantung pada kontribusi masing-masing variabel terhadap sifat mutu produk. Kemudian menentukan nilai terbaik dan terjelek dari data pengamatan serta menentukan bobot normal variabel yaitu bobot variabel dibagi dengan bobot total. Selanjutnya nilai efektivitas ditentukan dengan rumus:

Nilai efektivitas $=\frac{\text { nilai perlakuan-nilai terjelek }}{\text { nilai terbaik-nilai terjelek }}$

Selanjutnya menjumlahkan nilai hasil dari semua variabel dengan kombinasi perlakuan. Perlakuan terbaik dipilih dari kombinasi perlakuan dengan nilai total tertinggi.

\section{Sifat kimia}

Analisis sifat kimia roti tawar meliputi analisis kadar air menggunakan metode thermogravimetri (Sudarmadji et al., 2010), kadar abu (AOAC, 1995), kadar protein menggunakan metode mikrokjedhal (Sudarmadji et al., 2010), kadar lemak menggunakan metode Soxhlet (AOAC, 2005) dan kadarkarbohidrat menggunakan metode Carbohydrate by Difference (Apriyantono, 1989) serta analisis kadar serat kasar. 


\section{Kadar serat kasar}

Sampel seberat 1 gram diletakkan dalam gelas beker kemudian ditambahkan $50 \mathrm{ml} \mathrm{H}_{2} \mathrm{SO}_{4}$ 0,3 $\mathrm{N}$ dipanaskan selama 30 menit kemudian ditambah $25 \mathrm{ml} \mathrm{NaOH}$ 1,5 $\mathrm{N}$ untuk dipanaskan kembali selama 30 menit. Setelah itu, disaring dengan kertas saring yang telah dioven pada suhu 105$110^{\circ} \mathrm{C}$ selama 1 jam dan didinginkan di dalam eksikator selama 15 menit lalu ditimbang (A). Sisa saringan dicuci berturut-turut dengan $50 \mathrm{ml}$ air panas, 50 $\mathrm{ml} \mathrm{H}_{2} \mathrm{SO}_{4} 0,3 \mathrm{~N}, 50 \mathrm{ml}$ air panas dan terakhir $25 \mathrm{ml}$ aseton. Kertas saring dan isinya dimasukkan ke dalam cawan porselen dan dioven pada suhu $105-110^{\circ} \mathrm{C}$ sampai berat konstan kemudian dimasukkan dalam eksikator selama 15 menit lalu ditimbang (Y). Selanjutnya sampel dipanaskan dalam tanur pada suhu $600^{\circ} \mathrm{C}$ selama 6 jam dan didinginkan dalam eksikator selama 15 menit kemudian ditimbang $(\mathrm{Z})$.

\section{HASIL DAN PEMBAHASAN}

\section{SIFAT FISIK ROTI TAWAR KAYA SERAT \\ Tekstur}

Pengukuran tekstur pada roti tawar kaya serat dilakukan pada dua bagian yaitu bagian dalam (remah) dan bagian luar (kulit). Hasil pengamatan tekstur pada penelitian roti tawar kaya serat bagian dalam berkisar antara 29,80 - 115,47 g/10 $\mathrm{mm}$ dan pada bagian luar (kulit) berkisar antara 61,27 - 319,10 g/10 mm. Semakin banyak tepung ampas kelapa yang disubstitusikan maka nilai tekstur roti yang dihasilkan baik dari bagian dalam maupun bagian luar semakin besar. Nilai tekstur yang semakin besar menunjukan bahwa roti tawar memiliki tekstur semakin keras.

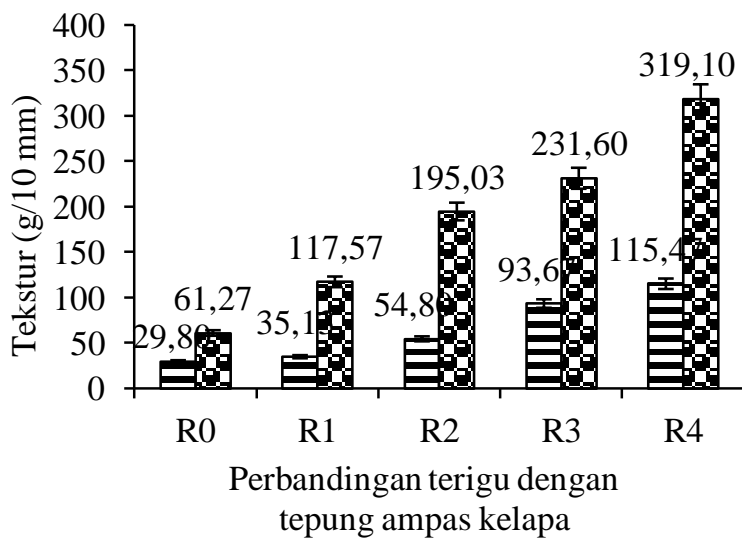

Gambar 1. Nilai tekstur roti tawar kaya serat substitusi tepung ampas kelapa (R0= $100 \%: 0 \%$; R1=95\%: 5\%; R2= $90 \%: 10 \% ; \mathrm{R} 3=85 \%: 15 \% ; \mathrm{R} 4=$ $80 \%: 20 \%$ ) pada bagian dalam (目) dan bagian luar roti ( $\mathbf{8})$

Gambar 1 menunjukkan nilai tekstur roti tawar kaya serat pada bagian dalam maupun luar tertinggi $(115,97 \pm 1,31$ $\mathrm{g} / 10 \mathrm{~mm}$ nilai tekstur bagian dalam; dan $319,10 \pm 0,72 \mathrm{~g} / 10 \mathrm{~mm}$ nilai tekstur bagian luar) pada perlakuan R4 dengan formulasi (terigu 80\%: tepung ampas kelapa 20\%), sedangkan nilai tekstur terendah $(29,80 \pm 0,7 \mathrm{~g} / 10 \mathrm{~mm}$ nilai tekstur bagian luar; dan $61,27 \pm 0,78 \mathrm{~g} / 10 \mathrm{~mm}$ nilai tekstur bagaian dalam) pada perlakuan R0 (terigu 100\%: tepung ampas kelapa $0 \%$ ). Semakin banyak penambahan tepung ampas kelapa akan menghasilkan nilai tekstur roti tawar kaya serat yang semakin tinggi atau semakin keras. Hal tersebut dikarenakan peningkatan substitusi tepung ampas kelapa dapat mengurangi jumlah protein gluten yang terdapat dalam adonan, sehingga tekstur yang dihasilkan tidak sebaik roti tawar dengan terigu $100 \%$.

Penurunan kandungan gluten dalam adonan roti tawar yang menyebabkan adonan lebih bersifat hidrofilik, sehingga terjadi interaksi lebih kuat diantara granula pati. Tekstur roti tawar erat hubungannya dengan pengkristalan fraksi amilopektin yang berlangsung secara perlahan-lahan setelah roti selesai dipanggang (Marleen, 2002). Gluten dalam pembuatan roti berfungsi untuk memerangkap dan 
menahan gas sehingga roti dapat mengembang dengan struktur beronggarongga halus dan seragam serta tekstur lembut dan elastis (Lasztity, 1984; Wahyudi, 2003). Oleh karena itu, semakin banyak penambahan tepung ampas kelapa maka tekstur yang dihasilkan semakin keras.

\section{Warna (Lightness)}

Warna merupakan parameter penting dan pertama dilihat oleh konsumen dalam memilih produk pangan. Warna yang menarik dan sesuai dengan keinginan konsumen menjadi daya tarik tersendiri dalam memilih makanan. Analisis nilai kecerahan (lightness) pada permukaan irisan (bagian dalam) dari roti tawar kaya serat substitusi tepung ampas kelapa menggunakan color reader pada 5 titik yang berbeda dengan 3 kali ulangan. Nilai lightness roti tawar kaya serat berkisar antara 22,06 - 32,84 (Gambar 2).

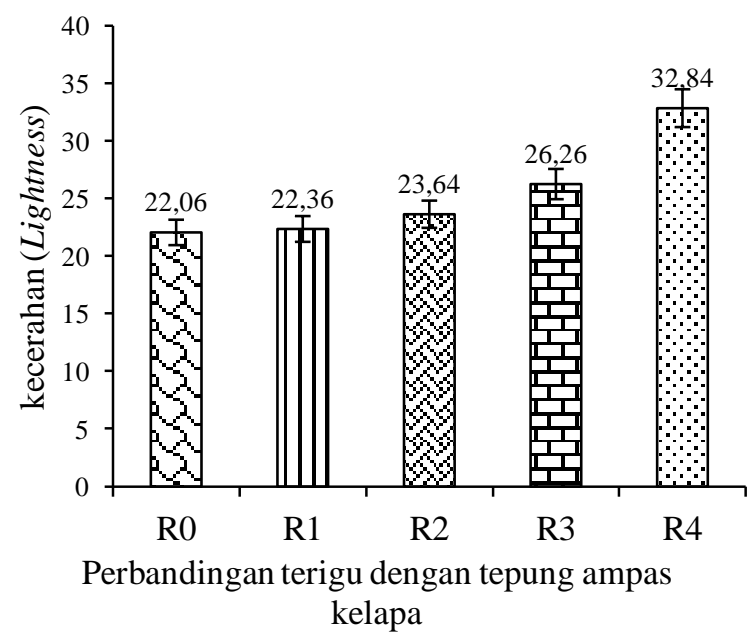

Gambar 2. Nilai lightness roti tawar kaya serat dengan substitusi tepung ampas kelapa $(\mathrm{R} 0=100 \%: 0 \% ; \mathrm{R} 1=95 \%: 5 \% ; \mathrm{R} 2=$ $90 \%: 10 \% ; \mathrm{R} 3=85 \%: 15 \% ; \mathrm{R} 4=$ $80 \%: 20 \%$ )

Gambar 2 menunjukkan bahwa semakin besar jumlah tepung ampas kelapa yang disubstitusikan maka nilai lightness semakin tinggi atau semakin cerah. Nilai lightness tertinggi pada perlakuan R4 dengan formulasi terigu
80\%: tepung ampas kelapa 20\%, sedangkan nilai lightness terendah pada perlakuan R0 dengan formulasi terigu 100\%: tepung ampas kelapa 0\% (kontrol). Lighness roti antara lain dipengaruhi noleh warna tepung sebagai bahan dasar dan tingkat reaksi maillard yang terjadi selama proses pemanggangan.

Nilai kecerahan tepung ampas kelapa lebih tinggi daripada terigu. Tepung ampas kelapa memiliki nilai kecerahan sebesar 88, sedangkan terigu nilai kecerahannya sebesar 74,94 - 76,38. Hal ini sesuai dengan pernyataan Murtini et al. (2005), bahwa nilai lightness dari terigu sebesar 74,94 - 76,38. Perbedaan nilai kecerahan tersebut yang menyebabkan tingkat kecerahan roti tawar semakin tinggi seiring meningkatnya substitusi tepung ampas kelapa.

Selain disebabkan oleh nilai kecerahan bahan dasar (terigu dan tepung ampas kelapa), kecerahan roti tawar juga disebabkan terjadinya reaksi maillard (reaksi antar gugus amina primer protein dan gugus karbonil gula reduksi. Semakin tinggi kandungan protein maka reaksi maillard semakin intensif dan warna roti semakin gelap (nilai kecerahan rendah) (Potter, 1988). Semakin banyak jumlah tepung ampas kelapa yang disubstitusikan, maka kadar protein dalam adonan semakin berkurang, sehingga warna roti semakin cerah.

\section{Daya kembang}

Daya pengembangan roti merupakan kemampuan roti mengalami pertambahan ukuran sebelum dan setelah proses pemanggangan. Hasil pengamatan pada penelitian produk roti tawar kaya serat menunjukkan nilai antara $69,14 \%-$ $188,59 \%$. Volume pengembangan roti tawar secara keseluruhan mengalami penurunan seiring dengan meningkatnya substitusi tepung ampas kelapa. Semakin banyak jumlah tepung ampas kelapa yang disubstitusikan ke dalam adonan roti tawar 
dapat menurunkan daya kembang roti tawar kaya serat.

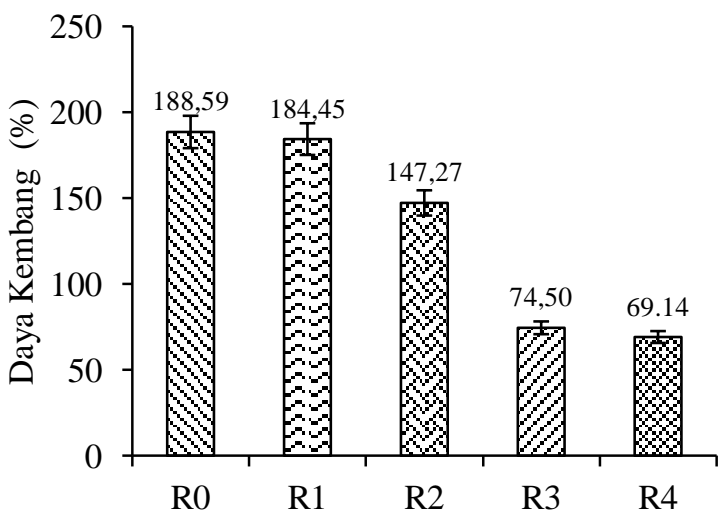

Perbandingan terigu dengan tepung ampas kelapa

Gambar 3. Nilai daya kembang roti tawar kaya serat dengan substitusi tepung ampas kelapa $(\mathrm{R} 0=100 \%: 0 \%$; R1= 95\% : $5 \%$; R2=90\% : 10\%; R3=85\%: $15 \%$; $\mathrm{R} 4=80 \%: 20 \%$ )

Pada Gambar 3 terlihat bahwa pada perlakuan R0 (kontrol) memiliki nilai daya kembang tertinggi yaitu 188,59 $\pm 0,81 \%$ dan untuk nilai daya kembang terkecil yaitu pada perlakuan R4 (terigu $80 \%$ : tepung ampas kelapa 20\%) dengan nilai $69,14 \pm 0,72 \%$. Perlakuan dengan nilai daya kembang mendekati kontrol yaitu R1 (terigu 5\%: tepung ampas kelapa 95\%). Volume pengembangan cenderung mengalami penurunan seiring dengan peningkatan tepung ampas kelapa yang disubstitusikan karena tepung ampas kelapa tidak mengandung gluten.

Semakin banyak tepung ampas kelapa yang disubstitusikan maka kandungan gluten yang terdapat di dalam adonan roti tawar kaya serat akan semakin sedikit, sehingga menurunkan daya kembang roti tawar yang dihasilkan. Hal ini dikarenakan gluten berfungsi untuk mempertahankan gas untuk mendapatkan volume dan tekstur yang diinginkan dalam sistem adonan. Tingkat pengembangan erat kaitannya dengan kemampuan adonan menahan gelembung-gelembung $\mathrm{CO}_{2}$ selama proses fermentasi (Wijayanti, 2007).

Daya kembang juga dipengaruhi oleh jumlah air yang diikat oleh adonan. Proses pemanggangan adonan mengalami kehilangan air. Hal ini menyebabkan lapisan gluten memerangkap dan memisahkan gas satu sama lain dengan membentuk lapisan pelindung menjadi buih kemudian menjadi tegar dan adonan mengembang (Potter, 1978).

\section{Staling}

Analisis staling dilakukan dengan cara penyimpanan roti tawar kaya serat dilakukan selama 3 hari pada suhu ruang dan diamati hari ke- 1, 2 dan 3 dengan mengukur tekstur bagian atas (luar) dan tengah (dalam) menggunakan rheotex. Nilai stalling didapatkan dari hasil selisih pengukuran tekstur baik dari bagian atas maupun tengah pada hari ke- 1, 2 dan $3(\Delta$ tekstur). Hasil pengamatan staling bagian atas (luar) dan tengah (dalam) pada hari ke 1, 2 dan 3 dapat dilihat pada Gambar 4 dan Gambar 5.

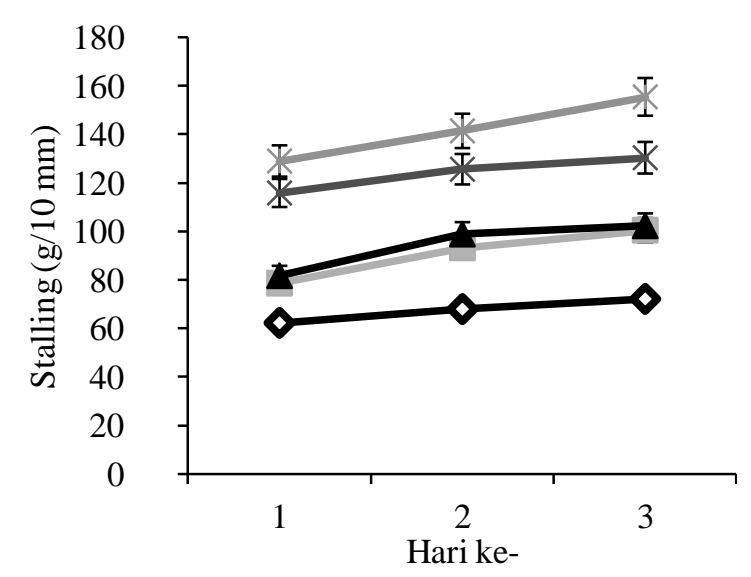

Gambar 4. Nilai staling (bagian luar) roti tawar kaya serat substitusi tepung ampas kelapa: R0 $=100 \%: 0 \%(\prec-)$; R1=

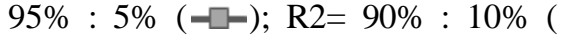
-上); R3=85\%: $15 \%$ (־); R4= $80 \%: 20 \%\left(-\frac{1}{*}\right)$ 


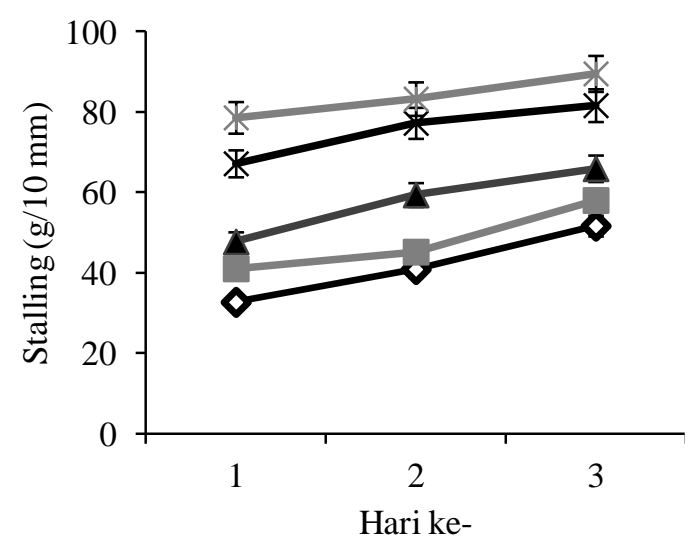

Gambar 5. Nilai staling (bagian dalam) roti tawar kaya serat substitusi tepung ampas kelapa: $\mathrm{R} 0=100 \%: 0 \%(\diamond-)$; R1=

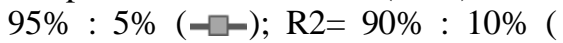
- $)$; R3=85\%: $15 \%(\longleftarrow)$; R4= $80 \%: 20 \%$ (争)

Gambar 4 dan Gambar 5 menunjukkan bahwa semakin banyak tepung ampas kelapa yang disubstitusikan maka nilai kekerasan selama 3 hari dari tekstur semakin tinggi dan semakin tinggi pula kecepatan staling pada roti tawar kaya serat. Kecepatan staling antara lain dipengaruhi oleh daya kembang dan berbanding terbalik dengan daya kembang. Semakin tinggi daya kembang maka kecepatan staling semakin rendah dan sebaliknya Hal ini karena kandungan gluten semakin berkurang dengan semakin meningkat jumlah tepung ampas kelapa yang disubstitusikan. Gluten berperanan untuk memerangkap dan menahan gas dalam pembuatan roti sehingga dihasilkan daya kembang tinggi (Lasztity, 1984; Satin, 1988).

Menurut Eliasson dan Larsson (1993), kecepatan staling berkurang seiring tingginya kandungan protein dalam bahan karena protein dapat berinteraksi dengan pati selama proses kristalisasi sehingga mengurangi kecepatan retrogradasi pati.

\section{Kenampakan Irisan}

Kenampakan irisan pada roti tawar dapat dilihat dari keseragaman dan kekompakan dari pori-pori atau lubang yang terbentuk di dalam roti tawar. Poripori roti yang baik adalah ukuran pori-pori yang kecil dan seragam di seluruh bagian crumb. Pori-pori roti merupakan lapisan tipis yang terbentuk pada gluten yang berfungsi untuk memerangkap karbondioksida. Pori-pori terbentuk pada proses fermentasi, pada saat itu aktivitas ragi mulai meningkat, adonan mengembang, dan volume adonan bertambah akibat produksi gas karbondioksida oleh ragi. Selain itu, gluten menjadi elastis dan lebih lembut akibat pengaruh alkohol, menurunnya kadar keasaman sehingga gluten membentuk lapisan tipis yang dapat menahan gas. Kenampakan irisan atau pori-pori roti tawar kaya serat dapat dilihat pada Gambar 6.

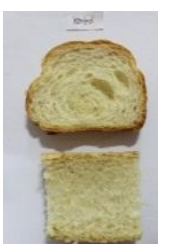

R0

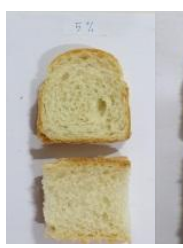

R1

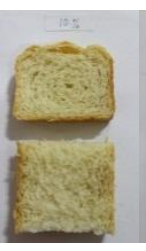

R2

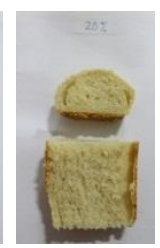

$\mathbf{R 3}$
$\mathbf{R 4}$
Gambar 6. Kenampakan irisan roti tawar perbandingan terigu dengan tepung ampas kelapa $(\mathrm{R} 0=100 \%: 0 \%$; $\mathrm{R} 1=95 \%: 5 \% ; \mathrm{R} 2=90 \%: 10 \%$; $\mathrm{R} 3=85 \%: 15 \% ; \mathrm{R} 4=80 \%: 20 \%$ )

Pada Gambar 6 terlihat bahwa semakin tinggi substitusi tepung ampas kelapa maka pori-pori yang dihasilkan semakin rapat. Hal ini karena kandungan gluten dalam adanan semakin berkurang, sehingga roti kurang mengembang dan dihasilkan remah roti yang rapat. Suhardjito (2006) juga menyatakan bahwa terbentuknya pori-pori pada roti tawar juga dipengaruhi oleh knocking down atau penggilasan yang menyebabkan pembentukan adonan menjadi relaks kembali sehingga timbul gas yang baru. 


\section{SIFAT ORGANOLEPTIK ROTI TAWAR KAYA SERAT}

Uji organleptik dilakukan oleh 30 panelis tidak terlatih untuk mengetahui tingkat kesukaan panelis terhadap roti tawar kaya serat. Parameter uji oranoleptik meliputi warna, aroma, rasa, tekstur dan keseluruhan dengan skala $1-7$. Hasil penilaian panelis terhadap uji kesukaan roti tawar kaya serat ditunjukkan pada Tabel 1.

Tabel 1. Skor kesukaan roti tawar kaya serat substitusi tepung ampas kelapa

\begin{tabular}{ccccc}
\hline \multirow{2}{*}{ Parameter } & \multicolumn{4}{c}{ Perlakuan } \\
\cline { 2 - 5 } & R1 & R2 & R3 & R4 \\
\hline Warna & 4,97 & 5,37 & 4,80 & 4,60 \\
Aroma & 4,90 & 5,30 & 4,67 & 4,17 \\
Rasa & 5,27 & 5,27 & 4,60 & 4,30 \\
Tekstur & 5,97 & 5,50 & 4,63 & 3,90 \\
Keseluruhan & 5,60 & 5,43 & 4,77 & 4,37 \\
\hline
\end{tabular}

Keterangan: $\mathrm{R} 1=$ terigu $95 \%$ : tepung ampas kelapa 5\%; R2 = terigu 90\% : tepung ampas kelapa 10\%; R3 = terigu $85 \%$ : tepung ampas kelapa 15\%; R4 = terigu $80 \%$ : tepung ampas kelapa $20 \%$.

\section{Warna}

Nilai kesukaan warna roti tawar kaya serat berkisar antara 4,60-5,37 (netral sampai suka). Nilai kesukaan warna tertinggi pada perlakuan R2 (substitusi terigu 90\% : tepung ampas kelapa 10\%) dengan skor 5,37 (agak suka sampai suka). nilai kesukaan terendah pada perlakuan $\mathrm{R} 4$ (substitusi terigu $80 \%$ : tepung ampas kelapa 20\%) dengan skor 4,60 (netral sampai agak suka). Jadi warna yang disukai adalah roti tawar kaya serat dengan nilai kecerahan sedang, yaitu pada perlakuan R2 (substitusi terigu 90\% : tepung ampas kelapa 10\%).

\section{Aroma}

Tabel 1 menunjukkan tingkat kesukaan aroma tertinggi pada perlakuan R2 (terigu 90\% : tepung ampas kelapa
$10 \%$ ) dengan skor 5,30 (agak suka sampai suka) dan nilai kesukaan terendah pada perlakuan R4 (terigu 80\% : tepung ampas kelapa 20\%) dengan skor 4,17 (netral sampai agak suka). Nilai tertinggi kedua setelah R2 yaitu pada perlakuan R1 (terigu 95\% : tepung ampas kelapa 5\%) dengan nilai 4,90 (netral sampai agak suka). Untuk nilai terendah kedua setelah R4 yaitu R3 (substitusi terigu 85\% : tepung ampas kelapa 15\%) sebesar 4,67 (netral sampai agak suka).

Hasil ini menunjukkan bahwa substitusi maksimal yang masih disukai sampai dengan substitusi 10\%. Bahanbahan yang digunakan dalam pembuatan roti tawar akan mempengaruhi aroma roti tawar yang dihasilkan. Semakin tinggi tingkat substitusi tepung ampas kelapa akan menurunkan nilai kesukaan panelis terhadap aroma roti tawar yang dihasilkan.

\section{Tekstur}

Menurut Mudjajanto dan Yulianti (2004), kriteria roti tawar yang baik adalah roti tawar yang memiliki tekstur roti lunak dan elastis. Tabel 1 menunjukkan bahwa semakin banyak penambahan tepung ampas kelapa, tekstur roti tawar yang dihasilkan semakin padat (bantat) dan sangat berbeda dengan roti tawar pada umumnya. Tingkat kesukaan panelis tertinggi pada uji kesukaan tektur yaitu perlakuan R1 (substitusi terigu 95\% : tepung ampas kelapa 5\%) dan terendah R4 (substitusi terigu 80 : tepung ampas kelapa 20\%).

Tekstur roti tawar dipengaruhi oleh beberapa faktor antara lain adanya kandungan protein, kadar air dan lemak dari bahan dasar pembuatan roti. Pori-pori roti tawar yang halus terbentuk karena udara masuk kedalam adonan dan terdispersi dalam bentuk gelembung yang halus ketika tepung dan air dicampur dan diulen, karena dalam tepung terigu mengandung protein yang mampu membentuk gluten ketika ditambah air dan perlakuan mekanis (Nur'aini, 2011). 
Pada sifat fisik untuk nilai tekstur bagian dalam (remah ) dari R0 - R4 berkisar antara 29,80 - 115,47 g/mm, sedangkan untuk bagian luar (kulit) berkisar antara 61,27 - 319,10 g/mm. tingkat kesukaan tekstur tertinggi oleh yaitu pada perlakuan R1 (substitusi terigu 95\% : tepung ampas kelapa 5\%) memiliki nilai $29,80 \mathrm{~g} / \mathrm{mm}$ (bagian dalam/remah) dan $61,27 \mathrm{~g} / \mathrm{mm}$ (bagian kulit/luar). Hal ini menunjukkan bahwa roti tawar kaya serat yang disukai dengan tekstur sedang.

\section{Rasa}

Pada Tabel 1 terlihat bahwa perlakuan R1 (substitusi terigu 95\% : tepung ampas kelapa 5\%) dan R2 (substitusi terigu 90\% : tepung ampas kelapa 10\%) memiliki nilai rasa yang sama yaitu 5,27 (agak suka sampai suka). Kemudian diikuti oleh perlakuan R3 (substitusi terigu $85 \%$ : tepung ampas kelapa 15\%) dan R4 (substitusi terigu 80\% : tepung ampas kelapa 20\%) masingmasing dengan nilai 4,60 (netral sampai agak suka) dan 4,30 (netral sampai agak suka). Rasa pada suatu produk dipengaruhi oleh komposisi bahan penyusun formula dalam bahan makanan. Semakin tinggi substitusi tepung ampas kelapa yang digunakan pada roti tawar, menyebabkan penurunan tingkat kesukaan.

Rasa umumnya dipengaruhi oleh bahan-bahan penunjang seperti telur, susu, gula, garam dan mentega. Selama proses fermentasi adonan, ragi mengubah karbohidrat menjadi gas $\mathrm{CO}_{2}$ dan etanol, selain itu ragi juga berperan dalam pembentukan cita rasa pada roti (Koswara, 2009). Fungsi utama yeast dalam pembuatan roti untuk mengembangkan adonan, membangkitkan aroma dan rasa dengan cara memecah gula/pati untuk menghasilkan $\mathrm{CO}_{2}$ sebagai pelunak gluten, menghasilkan etanol sebagai pemberi flavor pada proses fermentasi (Mudjajanto, 2008).

\section{Keseluruhan}

Kesukaan keseluruhan merupakan parameter yang diamati dari aspek warna, tekstur, aroma dan rasa untuk dinilai oleh panelis. Keseluruhan perlakuan pada roti tawar kaya serat dengan substitusi tepung ampas kelapa menunjukkan bahwa nilai tertinggi pada perlakuan R1 (substitusi terigu $95 \%$ : tepung ampas kelapa 5\%) dan terendah pada R4 (substitusi terigu $80 \%$ : tepung ampas kelapa 20\%) (Tabel 1).

Semakin banyak penambahan tepung ampas kelapa maka tingkat kesukaan terhadap parameter sensoris keseluruhan semakin menurun. Nilai kesukaan untuk tekstur dan rasa yang paling tinggi dan disukai yaitu pada perlakuan R1 (substitusi terigu 95\% : tepung ampas kelapa 5\%) dengan nilai masing-masing 5,97 dan 5,27 (agak suka sampai suka). Jadi kesukaan keseluruhan ditentukan oleh kesukaan tekstur dan rasa.

\section{NILAI EFEKTIVITAS}

Hasil uji efektivitas merupakan nilai dari bobot masing-masing perlakuan berdasarkan tingkat kepentingan parameter. Uji tersebut dilakukan untuk menentukan perlakuan terbaik dari sampel semua perlakuan. Berdasarkan data analisis dari sampel roti tawar kaya serat yang diperoleh maka dapat ditentukan bahwa bobot tertinggi yaitu 0,92 pada perlakuan R2 (terigu 90\% : tepung ampas kelapa 10\%). Nilai efektivitas dapat dilihat pada Tabel 2.

Tabel 2. Nilai efektivitas roti tawar kaya serat

\begin{tabular}{lc}
\hline \multicolumn{1}{c}{ Perlakuan } & $\begin{array}{c}\text { Nilai } \\
\text { Efektivitas }\end{array}$ \\
\hline $\begin{array}{l}\text { R1 (substitusi terigu 95\%: tepung } \\
\text { ampas kelapa 5\%) }\end{array}$ & 0,84 \\
$\begin{array}{l}\text { R2 (substitusi terigu 90\% : tepung } \\
\text { ampas kelapa 10\%) }\end{array}$ & 0,92 \\
$\begin{array}{l}\text { R3 (substitusi terigu 85\% : tepung } \\
\text { ampas kelapa 15\%) }\end{array}$ & 0,34 \\
$\begin{array}{l}\text { R4 (substitusi terigu 80\% : tepung } \\
\text { ampas kelapa 20\%) }\end{array}$ & 0,00 \\
\hline
\end{tabular}




\section{SIFAT KIMIA ROTI TAWAR KAYA SERAT}

Pemilihan produk terpilih dari roti tawar didasarkan pada uji efektivitas sehingga diperoleh R2 (terigu 90\% : tepung ampas kelapa 10\%). Produk roti tawar kaya serat (R2) terpilih dianalisis sifat kimianya. Hasil analisisnya dapat dilihat pada Tabel 3 .

Tabel 3. Sifat kimia produk roti tawar kaya serat terpilih

\begin{tabular}{|c|c|c|c|}
\hline \multirow[b]{2}{*}{ Komponen } & \multicolumn{3}{|c|}{ Kadar (\%) } \\
\hline & $\begin{array}{c}\text { Kandungan } \\
\text { kimia }(\%)\end{array}$ & SNI & $\begin{array}{c}\text { Direktorat } \\
\text { Gizi } \\
\text { Depkes RI } \\
(\%)\end{array}$ \\
\hline Kadar air & $39,07 \pm 0,12$ & $\begin{array}{l}\text { Maks. } \\
40\end{array}$ & 37,7 \\
\hline Kadar abu & $1,47 \pm 0,15$ & $\begin{array}{c}\text { Maks. } \\
1\end{array}$ & - \\
\hline Kadar protein & $9,59 \pm 0,3$ & - & 9,7 \\
\hline Kadar lemak & $5,77 \pm 0,49$ & - & 4,2 \\
\hline $\begin{array}{l}\text { Kadar } \\
\text { karbohidrat }\end{array}$ & $44,11 \pm 0,72$ & - & 49,7 \\
\hline $\begin{array}{l}\text { Kadar serat } \\
\text { kasar }\end{array}$ & 5,69 & - & 2,95 \\
\hline & $\begin{array}{l}\text { I } \quad(1995) \\
\text { kes RI (199 }\end{array}$ & Di & orat Gizi \\
\hline
\end{tabular}

\section{Kadar air}

Kadar air merupakan salah satu parameter penting unutk produk-produk kering karena kecenderungan kerusakan pada suatu produk pangan. Roti tawar termasuk jenis roti basah sehingga kadar airnya cukup tinggi yang menyebabkan daya awetnya rendah. Pada Tabel 3 terlihat bahwa kadar air roti tawar kaya serat memiliki nilai 39,07\%. Menurut syarat mutu Standar Nasional Indonesia (SNI) 01-3840-1995, kadar air roti tawar gandum maksimal 40\%. Dengan demikian, kadar air roti tawar kaya serat memenuhi syarat SNI.

\section{Kadar abu}

Berdasarkan syarat mutu Standar Nasional Indonesai (SNI) 01-3840-1995, kadar abu maksimal roti tawar sebesar $1 \%$. Kadar abu pada roti tawar kaya serat sebesar $1,47 \pm 0,15 \%$. Kadar abu pada produk roti tawar kaya serat melebihi batas maksimal yang ditetapkan SNI. Hal ini dikarenakan adanya penambahan tepung ampas kelapa yang memiliki kadar abu sebesar $0,52 \%$ dan kadar abu terigu 2,2\%. Besarnya kadar abu produk pangan bergantung pada besarnya kandungan mineral bahan yang digunakan (Sudarmadji et al., 2010).

\section{Kadar protein}

Protein merupakan zat makanan yang penting bagi tubuh. Hal tersebut dikarenakan protein berfungsi sebagai bahan bakar dalam tubuh, zat pembangun dan pengatur tubuh (Winarno, 2004). Kadar protein roti tawar kaya serat produk terpilih sebesar 9,59 $\pm 0,3 \%$ (Tabel 3). Kadar protein pada roti tawar salah satunya dipengaruhi oleh jenis tepung yang digunakan. Tepung yang digunakan pada pembuatan roti tawar adalah tepung terigu berprotein tinggi (hard wheat) dengan kandungan gluten yang tinggi, sehingga penggunaan terigu dapat menambah kandungan protein pada roti tawar.

Berdasarkan Direktorat Gizi Depkes (1992), kadar protein roti tawar gandum sebesar 9,7\%. Hal ini menunjukkan bahwa kandungan protein pada roti tawar kaya serat memiliki nilai yang mendekati kadar protein roti tawar gandum sehingga produk roti tawar kaya serat yang disubstitusi tepung ampas kelapa sudah layak dan sesuai standar gizi.

\section{Kadar lemak}

Tabel 3 menunjukkan bahwa kandungan lemak roti tawar kaya serat subtitusi tepung ampas kelapa sebesar 6,13 $\pm 0,49 \%$. Berdasarkan Direktorat Gizi Depkes (1992), kadar lemak maksimal roti tawar sebesar 4,2\%. Roti tawar dengan substitusi tepung ampas kelapa meningkatkan kadar lemak. Kandungan lemak yang tinggi pada roti tawar kaya serat disebabkan oleh tepung ampas kelapa 
yang digunakan. Kandungan lemak tepung ampas kelapa adalah sebesar 47,68\%.

Putri (2010) menyatakan bahwa kandungan lemak pada tepung ampas kelapa dengan perlakuan blanching sebesar $38,27 \%$. Semakin tinggi kandungan lemak yang dimiliki oleh bahan pembuatan roti tawar, maka semakin tinggi pula kandungan lemak yang dihasilkan oleh produk meskipun hanya $10 \%$ substitusi tepung ampas kelapa.

\section{Kadar karbohidrat}

Karbohidrat memiliki peranan penting dalam menentukan karakteristik bahan makanan, seperti rasa, warna, tekstur dan lain-lain. Tabel $\mathbf{3}$ menunjukkan kadar karbohidrat yang dimiliki oleh roti tawar substitusi ampas

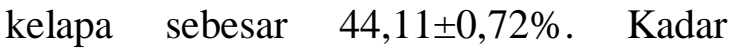
karbohidrat yang didapat merupakan hasil perhitungan dengan metode carbohydrate by difference (Apriyantono, 1989). Kadar karbohidrat roti tawar sebesar $44,11 \pm 0,72 \%$ lebih rendah dibandingkan kadar karbohidrat dari Direktorat Gizi Depkes (1992).

\section{Kadar serat kasar}

Serat (fiber) dapat dibedakan atas serat kasar (crude fiber) dan serat makanan (dietary fiber). Serat kasar (crude fiber) adalah serat tumbuhan/tanaman yang tidak larut dalam asam (H2SO4 1,25\%) dan basa $(\mathrm{NaOH} 1,25 \%)$. Nilai serat kasar lebih rendah daripada serat makanan karena $\mathrm{H} 2 \mathrm{SO} 4$ dan $\mathrm{NaOH}$ mempunyai kemampuan lebih besar untuk menghidrolisis komponen makanan dibandingkan dengan enzim pencernaan.

Kadar serat makanan berkisar antara 2-3 kali serat kasar. Komponen utama serat kasar disusun oleh selulosa, gum, hemiselulosa, pektin dan lignin (Muchtadi, 1992). Kandungan serat kasar pada roti tawar kaya serat (substitusi tepung ampas kelapa) terpilih sebesar 5,69\% (Tabel 3). Hal ini dikarenakan kadar serat tepung ampas kelapa lebih besar 15,06\% dibandingkan tepung terigu 0,25\% (Utomo dan Antarlina, 1997).

\section{KESIMPULAN}

Semakin banyak substitusi tepung ampas kelapa pada pembuatan roti tawar kaya serat mengakibatkan tekstur roti semakin keras pada bagian dalam maupun luar, warna (lightness) semakin cerah, laju kecepatan staling semakin meningkat, pori-pori yang terbentuk semakin kompak dan rapat. Daya kembang roti tawar kaya serat mengalami volume penurunan seiring meningkatnya substitusi tepung ampas kelapa.

Roti tawar kaya serat substitusi tepung ampas kelapa yang paling disukai oleh panelis adalah roti tawar dengan perlakuan terigu 90\% : tepung ampas kelapa $10 \%$. Roti tawar yang dihasilkan memiliki tekstur bagian dalam sebesar $54,80 \mathrm{~g} / 10 \mathrm{~mm}$ dan bagian luar (kulit) 195,03 g/10 mm; lightness 23,64; daya kembang $147,27 \pm 1,4 \%$; kadar air

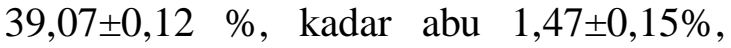
kadar protein $9,59 \pm 0,3 \%$, kadar lemak $6,13 \pm 0,49 \%$, karbohidrat 44,11 $\pm 0,72 \%$; dan kandungan serat kasar sebesar 5,69\%; serta tingkat kesukaan warna, aroma, rasa, tekstur dan keseluruhan berturut-turut yaitu 5,37; 5,30; 5,27; 5,50; 5,43 (agak suka sampai suka).

\section{DAFTAR PUSTAKA}

Arlene, A. 2009. "Pembuatan Roti Tawar dari Tepung Singkong dan Tepung Kedelai". Skripsi. Fakultas Teknologi Industri, Universitas Katolik Parahyangan, Bandung.

Apriyantono A., D. Fardiaz., N. L. Puspitsari., Sedamawati dan S. Budiyanto. 1989. Analisis Pangan PAU Pangan dan Gizi. IPB Press, Bogor.

Association of Official Analytical Chemist (AOAC). 2005. Official Method of Analysis of the Association of Analytical Chemist. Association of Official Chemist, Washington D.C. 
Aurand W.L., A. E. Wood., R. M. Wells. 1987. Food composition and analysis, 4 th edition, Van Nostrand Reinhold, 115 fifth avenue. New York, pp. 19-34.

Bakrie, A. 1990. Mempelajari Pengaruh Penggunaan Tepung Campuran Terigu dan Tapioka Terhadap Mutu Roti Manis. Pusat Penelitian Universitas Jember, Jember.

Eliason, A. C., dan K. Larsson. 1993. Cereals in Breadmaking. Marcel Dekker, Inc., New York.

Direktorat Gizi Departemen Kesehatan RI. 1992. Daftar Komposisi Bahan Makanan. Penerbit Bhratara, Jakarta.

Herawati, B., Y. Kusbiantoro., Rismayanti dan Mulyani. 2005. Pemanfaatan Limbah Pembuatan VCO. Prosiding Seminar Nasional, Yogyakarta.

Koswara, S. 2009. Teknologi pengolahan roti. Http://www.ebookpangan.com [Diakses tanggal 28 Februari 2018].

Lasztitiy, R. 1984. The Chemistry of Cereal Protein. CRC Press, Inc. Baca Raton, Florida.

Listiyarini,T. 2016. Naik ke peringkat 2 dunia impor gandum RI capai 8,1 juta ton. http://www.beritasatu.com/ekonomi/337 466-naik-ke-peringkat-dua-duniaimporgandum-ri-capai-81-juta-ton.html [Diakses tanggal 17 juli 2017].

Marleen, H. 2002. Efek substitusi tepung terigu oleh tepung campuran kedelai dan ubi jalar serta penambahan gliseril monostearat pada pembuatan roti tawar. Seminar Nasional PATPI Malang, Hal B29 - B74.

Matz, S. A. 1992. BakeryTechnology and Engineering. Van Vostrand Reinhold, New York.

Mudjajanto, S.E. dan L.N.Yulianti. 2004. Membuat Aneka Roti. Penerbit Swadaya, Jakarta.
Murtini, E.S., T. Susanto., dan R. Kusumawardhani. 2005. Karakteristik fisik, kimia, dan fungsional tepung gandum lokal varietas selayar, nias dan dewata gandum lokal varietas selayar. Jurnal Teknologi Pertanian, 6 (1): 5765.

Muchtadi, D. 1992. Petunjuk Laboratorium Evaluasi Nilai Gizi Pangan. Pusat Antar Universitas, Pangan dan Gizi IPB, Bogor. 216 pp.

Nur'aini, A. 2011. “Aplikasi Millet (Pennisetum Spp) Merah dan Millet Kuning sebagai Substitusi Terigu dalam Pembuatan Roti Tawar : Evaluasi Sifat Sensoris dan Fisikokimia". Skripsi. Universitas Sebelas Maret, Surakarta.

Potter, N. N. 1978. Food Science. Third Ed. The Avi Publishing Co. Inc. Wessport, Connecticut.

Putri. M. F. 2010. "Kandungan Gizi dan Sifat Fisik Tepung Ampas Kelapa sebagai Bahan Pangan Sumber Serat". Skripsi. Fakultas Teknik, Universitas Negeri Semarang, Semarang.

Rony, P. 1993. Aneka Produk Olahan Kelapa. Penebar Swadaya, Jakarta.

Standar Nasional Indonesia (SNI).01-38401995. Syarat Mutu Roti Tawar. Dewan Standar Nasional, Jakarta.

Sudarmaji, S., B. Haryono dan Suhardi. 1997. Prosedur Analisa untuk Bahan Makanan dan Pertanian. Liberty, Yogyakarta.

Sudarmo. 2015. "Eksperimen Pembuatan Roti Tawar Subtitusi Tepung Kulit Ari Kedelai". Skripsi. Universitas Negeri Semarang, Semarang.

Wahyudi. 2003. Memproduksi Roti. Direktorat Pendidikan Menengah Kejuruan Direktorat Jenderal Pendidikan Dasar dan Menengah Departemen Pendidikan Nasional, Jakarta. 
Wijayanti, 2007. "Substitusi Tepung Gandum

(Triticum aestivum) dengan Tepung

Garut (Maranta arundinaceae L) pada

Pembuatan Roti Tawar". Skripsi.

Fakultas Teknologi Pertanian,

Universitas Gadjah Mada, Yogyakarta.

Winarno, F.G. 2004. Kimia Pangan dan Gizi

Gramedia Pustaka Utama, Jakarta. 